\title{
Phylogenetic relationships within Turneraceae based on morphological characters with emphasis on seed micromorphology
}

\author{
María M. Arbo • Ana M. Gonzalez • \\ Silvana M. Sede
}

Received: 18 September 2014/ Accepted: 23 February 2015/Published online: 31 March 2015

(C) Springer-Verlag Wien 2015

\begin{abstract}
Genera of Turneraceae differ notably in connation/adnation of calyx, corolla, and androecium. Floral and seed morphology were analyzed in all genera. Phylogenetic analyses were made using a matrix of 91 characters coded for 102 taxa including all genera of Turneraceae and all series of Turnera. Our goals were: assessing the impact of morphology in the cladistic analyses of Turneraceae and comparing our results with those based on molecular datasets. Our analyses suggest that all genera are monophyletic. The inclusion of seed micromorphology in the analyses increased resolution within Turnera, the strict consensus tree shows four main clades, each gathering two or more current series. A comparison of morphological and molecular trees is difficult to make due to the great differences in taxon sampling. However, some clades or subclades are consistent in both phylogenetic approaches. Apparently, the formation of a floral tube conferred an evolutionary advantage to the Turneraceae, because it developed in $66 \%$ of the genera. The morphological complexity of the tube increased in several steps: (1) adnation
\end{abstract}

Handling editor: Ricarda Riina.

Electronic supplementary material The online version of this article (doi:10.1007/s00606-015-1204-3) contains supplementary material, which is available to authorized users.

M. M. Arbo ( $\square)$ · A. M. Gonzalez

Facultad de Ciencias Agrarias, Instituto de Botánica del

Nordeste, CONICET-Universidad Nacional del Nordeste,

Sargento Cabral 2131, CC 209, K3400CBR Corrientes,

Argentina

e-mail: arbo.mercedes45@gmail.com; arbo@agr.unne.edu.ar

S. M. Sede

Instituto de Botánica Darwinion (CONICET-ANCEFN),

Labardén 200, CC 22, B1642HYD San Isidro, Argentina of petal claws to calyx, developing a perianth tube; (2) partial adnation of stamens to the perianth tube; (3) fusion of sepal and petal veins, shaping a 10-veined perianth tube; (4) development of nectar pockets up to the throat turning the tube into an appendicular hypanthium. The reddishorange aril, associated with ornitochory, is plesiomorphic in Turneraceae, represented only in Erblichia; the other genera have white/whitish aril, associated with mirmecochory, except Mathurina, with an aril divided into filaments as an adaptation to anemochory.

Keywords Adnation - Africa A America - Connation · Floral morphology $\cdot$ Seed micromorphology

\section{Introduction}

The family Turneraceae holds 226 species and 12 genera. Adenoa Arbo (1 sp.), Erblichia Seeman (1 sp.) and Piriqueta Aubl. (45 spp.) occur in the Americas, while Afroqueta Thulin \& Razafim. (1 sp.), Hyalocalyx Rolfe (1 sp.), Loewia Urb. (1 sp.), Stapfiella Gilg (6 spp.), Streptopetalum Hochst. (6 spp.) and Tricliceras Thonn. ex DC. (16 spp.) occur in Africa. Arboa Thulin \& Razafim. (4 spp.) is endemic to Madagascar, and Mathurina Balf. f. (1 sp.) is endemic to the Mascarene Islands. Turnera L. has 141 native species in the Americas and two in Africa, which are at present arranged into 11 series, hereafter abbreviated as "ser." (Table 1). Turneraceae is closely related to Passifloraceae and Malesherbiaceae, and the three of them are treated together as Passifloraceae s.l. in the APG III (2009). Sequences from 25 genera and 42 species of Passifloraceae s.l. were analyzed phylogenetically by Tokuoka (2012). According to his results, the monophyly of Passifloraceae s.l. and that of Turneraceae, Malesherbiaceae and 


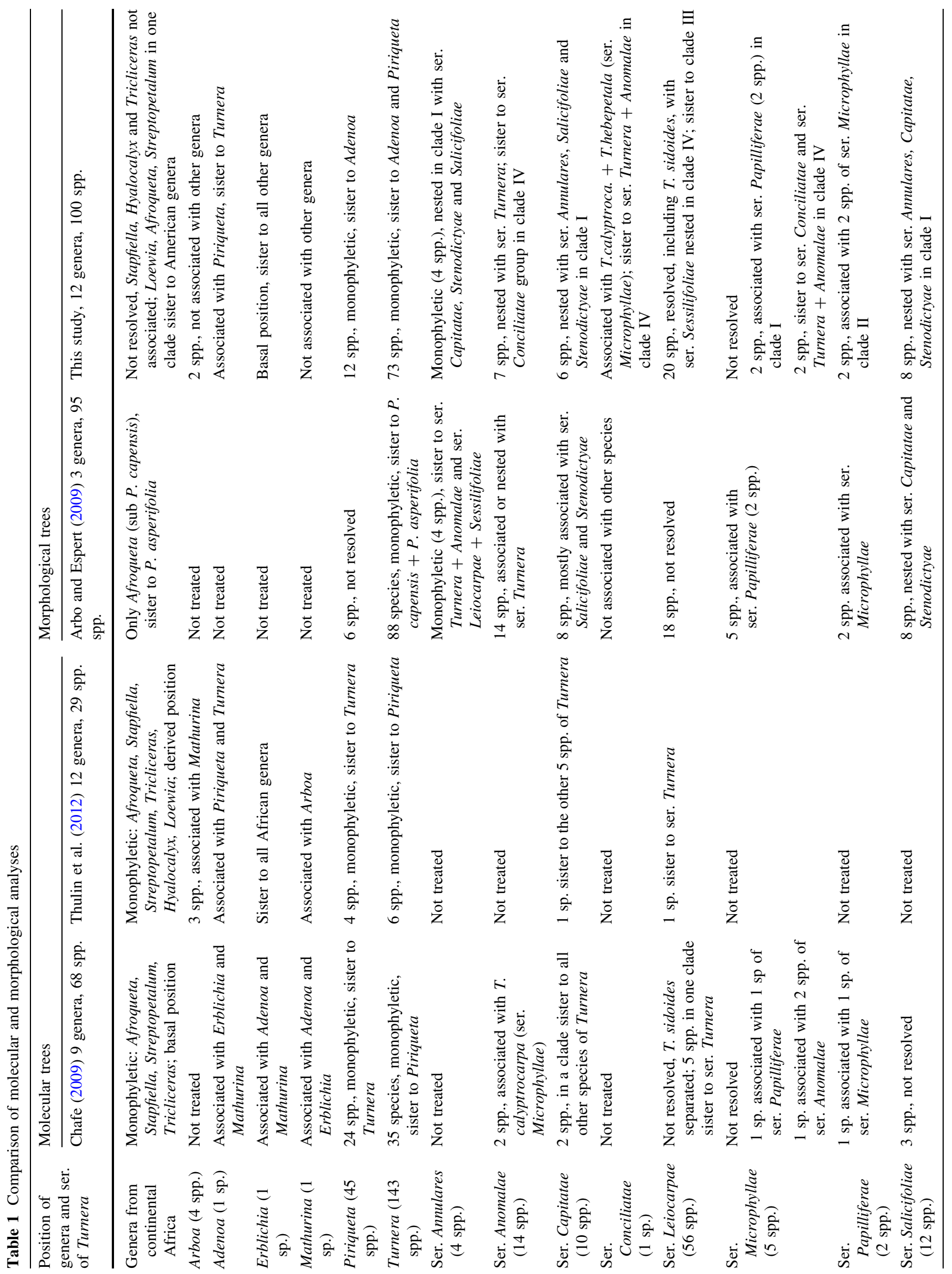


Passifloraceae sensu stricto, are strongly supported. Urban's monography (1883) and the revisions of the neotropical genera (Arbo 1977, 1979, 1995, 1997, 2000, 2005, 2008) highlighted the relevance of seed characters for taxonomy. In these studies, the authors described seed shape, size, color, curvature, type of coat (episperm), as well as the degree of chalaza development and orientation, shape of the exostome, and relative length and width of the aril. Some details were also considered, such as the presence of outstanding knots on the seed coat reticule and of punctiform cavities in each areole, and the type of cells forming the aril.

The first molecular phylogenetic study of Turneraceae included 5 species of Piriqueta and 35 American species belonging to seven series of Turnera (Truyens et al. 2005). According to their results, Turnera was monophyletic, and series Turnera was the only monophyletic series. Afterwards, cladistic analyses of the genus Turnera (92 species) based on morphological characters and chromosome numbers were made to test the monophyly of the series, and to assess biogeographic patterns (Arbo and Espert 2009).

Chafe (2009) conducted further analyses including all the species of Turnera sequenced in Truyens et al. (2005), Adenoa, Erblichia, Mathurina, some additional species of Turnera, many other species of Piriqueta and species of four African genera. His results varied depending on the method used to analyze the data (parsimony, maximum likelihood, or Bayesian inference). Nevertheless, some clades as Piriqueta and Turnera ser. Turnera were consistent across methods, as well as the isolated position of Piriqueta capensis, which is currently treated as the monotypic genus Afroqueta (Thulin et al. 2012). The molecular phylogenetic tree that so far includes the largest number of species of Turneraceae is illustrated in Chafe's thesis (2009, Fig. 11): 68 species of 9 genera, missing only the African genera Arboa, Hyalocalyx and Loewia. The tree comprises 24 species of Piriqueta and 35 of Turnera, corresponding to seven series. The African genera Afroqueta, Stapfiella, Streptopetalum and Tricliceras are found in a clade sister to all other Turneraceae. Adenoa, Mathurina and Erblichia appear closely related, and Turnera and Piriqueta are sister clades.

The most recent molecular phylogenetic study (Thulin et al. 2012) includes 29 species representing all the genera. Their Bayesian majority rule consensus tree shows two well-supported clades structured geographically: the basal one with the American taxa and the two African Turnera species, and the other with the African genera and the American Erblichia odorata. Unfortunately, this study, the only one including all the genera of the family, sampled very few species of Turnera.

Evolution is intimately linked to changes in chromosome number and karyotype. The ancestral base number in 
Turneraceae might be $x=7$, found in Piriqueta, Turnera and Adenoa (Fernández 1987; Gonzalez et al. 2012). However, chromosome numbers are unknown for the African genera. The genus Turnera including $66 \%$ of the species of the family has three base chromosome numbers: $x=7, x=5$ and $x=13$ (Fernández 1987), and polyploidy has played an important role in speciation, given that several species, including T. ulmifolia L. (type of the genus) are allopolyploids (Shore et al. 2006). At present, Turnera is divided into 11 series, but critical information to change taxonomic circumscriptions is still missing, since the base number of ser. Annulares, ser. Capitatae, ser. Conciliatae and ser. Sessilifoliae is unknown. Finally, none of the species of four series: ser. Annulares, ser. Conciliatae, ser. Sessilifoliae and ser. Stenodictyae has yet been included in a molecular phylogenetic analysis.

The present research focused on the micromorphology of seeds in all genera of Turneraceae, as well as the comparison of floral and fruit traits important in the delimitation of genera. The goals of our study were: (1) to assess the impact of morphological attributes and seed micromorphology in the cladistic analyses of the family; (2) to compare our results with those based on molecular datasets.

\section{Materials and methods}

This study includes 101 taxa representing all twelve genera in the family Turneraceae, and all the series of Turnera. The species and specimens analyzed with collector, number, source, and herbaria are listed in Online Resource 1. All known allopolyploid species were excluded, as in Arbo and Espert (2009), because they are the products of reticulate evolution. A species of Passiflora was used as outgroup. Seeds were gold/palladium coated for the scanning electron microscope (SEM) analysis. We used the Jeol 5800 LV SEM of the electron microscopy service of the 'Universidad Nacional del Nordeste', Corrientes. Some photographs were taken at Washington University, St. Louis, USA and York University, Toronto, Canada. Seeds of Erblichia were microtome sectioned to verify the nature of the endotesta, following techniques described in Gonzalez et al. (2012) and Gonzalez and Arbo (2013).

The list of characters and character states is provided in Online Resource 2. Each time a character is mentioned in the text, the corresponding number is shown between square brackets. We considered all morphological characters used by Arbo and Espert (2009) in Turnera and Piriqueta and base chromosome numbers. To cover generic variability, it was necessary to add states in some characters. Variable characters at generic level [19, 27, 29, 33, 35,
36, 39, 41, 44, 45] and 34 features resulting from the micromorphological analysis of seed were included. In the case of continuous characters, three ranges (minimummedium-maximum) were settled and the average was considered for each species.

Areoles were measured at the region of maximum seed diameter, but given the variable areole size in individual seeds, only the areoles of largest size, corresponding to the antiraphe, were measured and the average was calculated. Whenever possible, SEM photographs were used for character coding; they were supplemented with observations at the maximum magnification $(40 \times)$ of a stereoscopic microscope Leica Wild M3C equipped with double incident light (lateral and vertical).

The morphological matrix was analyzed using the maximum parsimony criterion implemented in the software TNT ver. 1.1 (Goloboff et al. 2008a). The states of the characters [18, 19, 25, 26, 90] related with the evolution of the floral tube, present in the majority of the genera, were ordered according to its development. The missing characters were coded with a question mark, and the inapplicable ones with a hyphen. The data matrix is available upon request to the corresponding author.

Analyses considering all characters with equal weights detected high levels of homoplasy. Consequently, analyses with different implied weighting schemes were carried out. Different characters do not provide equally strong evidence (some display high levels of homoplasy while others are perfectly hierarchical). Therefore, trees obtained from properly weighted characters are desirable (Goloboff 1993). Moreover, down-weighting morphological characters according to their homoplasy produce more strongly supported groups and more stable results (Goloboff et al. 2008b). The implied weighting method consists of estimating character weights according to their homoplasy. The "character fit", as defined by Goloboff (1993), is a concave function of the character's homoplasy (i.e., number of extra steps), and trees with maximum total fit are searched for. The "fittest" tree implies that the characters are maximally reliable and, given character conflicts, they are solved in favor of those characters that have less homoplasy. The degree of the concave function can be modified in TNT through the constant $k$, where lower $k$ values penalize homoplastic characters harder than higher values of $k$. When using implied weights, it is not clear how much a homoplastic character should be down-weighted; therefore, we explored different values of $k$ and chose 2-4, because with these values, homoplasy was hardly penalized and very similar trees were retrieved. The searching procedure involved a driven search finding the minimum length 10 times with default settings for sectorial searches and tree fusing (Goloboff 1999). The resulting trees were 
additionally TBR swapped. Bremer support (Bs; Bremer 1994) and Jackknife (JK; Farris et al. 1996) were used to estimate branch support. Bs was estimated on the basis of 10,000 suboptimal trees of $0.01-0.5$ less fit and for each value of $k$. For the JK analyses, the matrix was resampled 1000 times, with a probability of character removal $p=0.36$. Values were expressed as absolute frequencies.

Morphological characters, including homoplastic ones, were optimized on one of the most parsimonious trees randomly selected from the analysis. The homoplastic characters were optimized because they define groups within the family or represent diagnostic features for Turnera.

\section{Results}

The numbers shown between square brackets indicate the corresponding number of each character listed in Online Resource 2.
Adnation and connation of floral whorls

Within Turneraceae, sepals, petals and staminal filaments show noteworthy variation in connation (merging of pieces of the same verticil) and adnation (adherence, fusion of pieces from different whorls).

Erblichia, Arboa, Mathurina and Stapfiella (Fig. 1) have free or almost free sepals [18]. All the other genera possess a tube of variable nature, length of connation [18] and number of major veins [19]. Hyalocalyx (Fig. 1) is the only genus in which the tube is formed only by the calyx, because the petals are adnate [90] only at the base to the calyx tube; in the remaining genera, the petal claws are adnate to the calyx, developing a perianth tube.

In Hyalocalyx, Tricliceras, Streptopetalum (Fig. 1) and Afroqueta (Fig. 2), the tube has 15 veins [19], i.e., sepals connation does not involve the fusion of the sepals lateral veins. In Tricliceras (Fig. 1), the petal claws are adnate to the calyx tube along $1 / 3-1 / 2$ of its length, while in Streptopetalum (Fig. 1) they are adherent to the calyx tube up to
Fig. 1 Floral morphology in Turneraceae: Erblichia, Arboa, Mathurina and Stapfiella with free sepals, Hyalocalyx with calyx tube, Tricliceras and Streptopetalum with perianth tube. On the left, part of the calyx inner face with basal portions of petals and staminal filaments; the adnate portions are indicated with thick dotted lines. On the right, cross section of flower showing the relationships between whorls; the principal veins are represented with dots

\section{Erblichia}

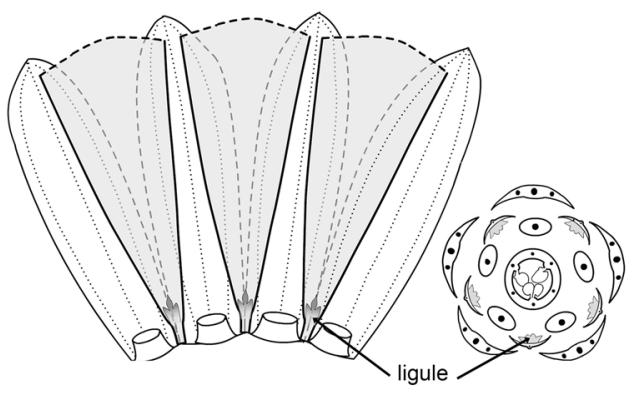

Mathurina - Stapfiella

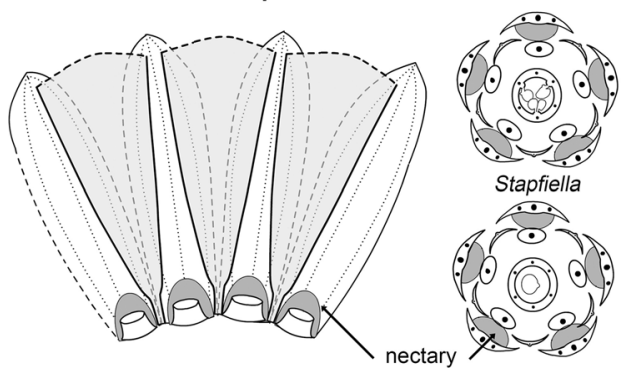

Tricliceras

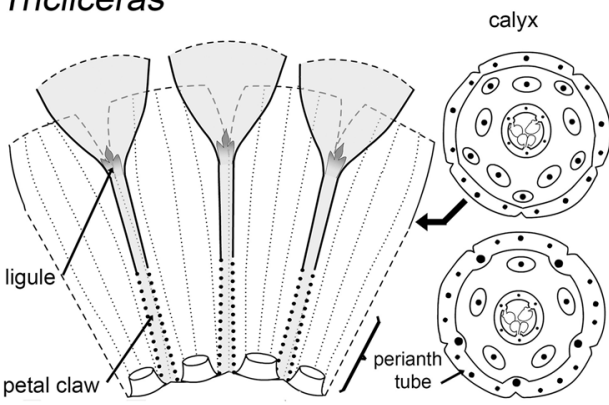

Arboa

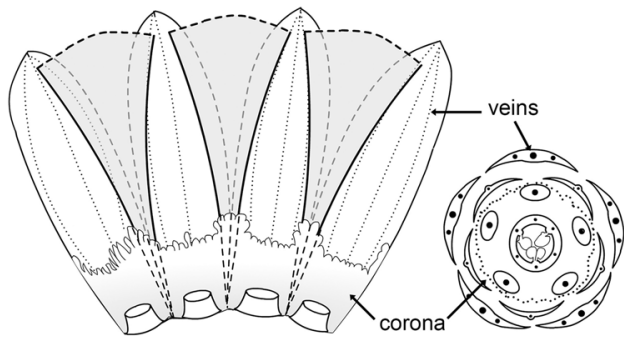

Hyalocalyx

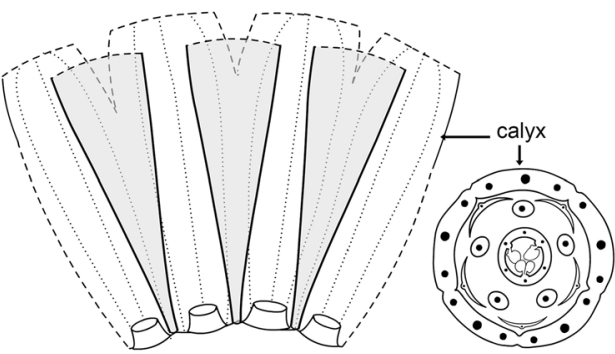

Streptopetalum

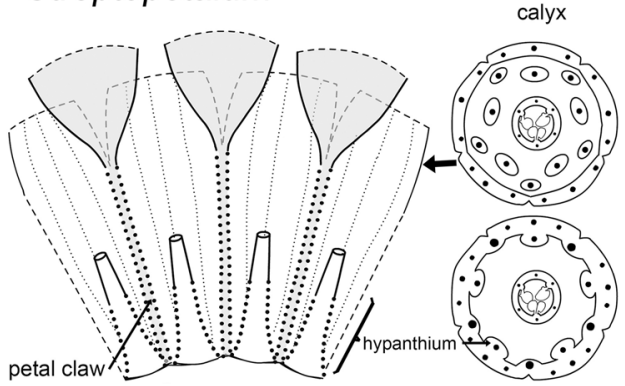


Fig. 2 Floral morphology in Turneraceae: Loewia, Afroqueta, Adenoa, Piriqueta and Turnera with perianth tube, Turnera ser. Anomalae and ser. Turnera with hypanthium. On the left, part of the calyx inner face with basal portions of petals and staminal filaments; the adnate portions are indicated with thick dotted lines. On the right, cross section of flower showing the relationships between whorls; the principal veins are represented with dots
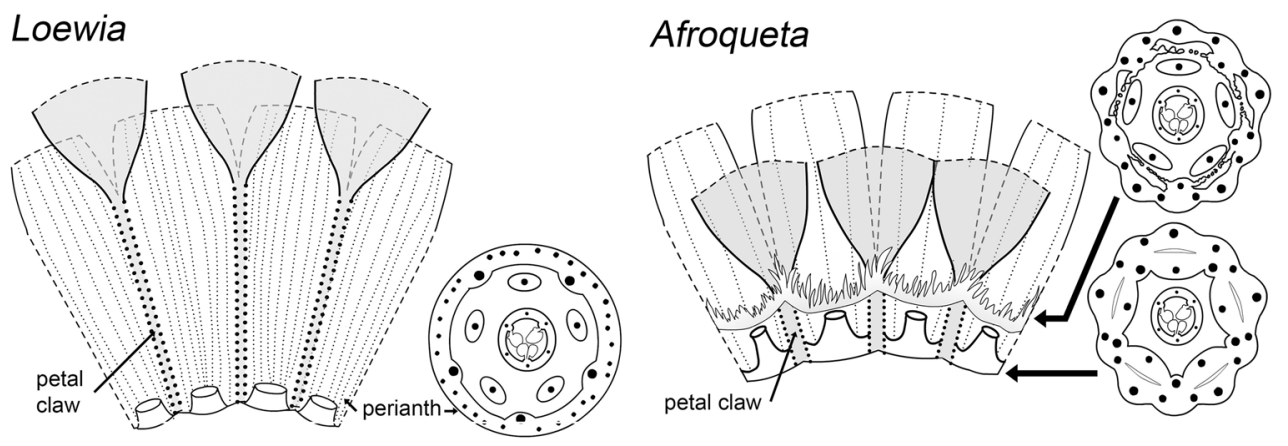

Adenoa

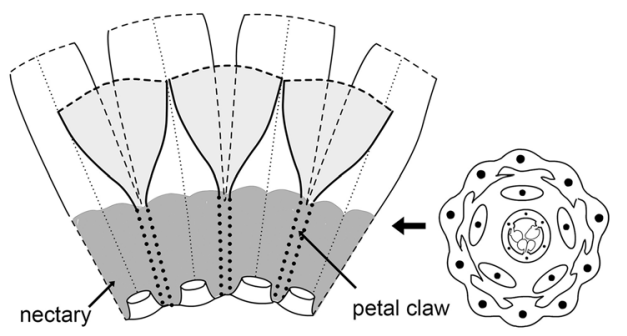

Piriqueta

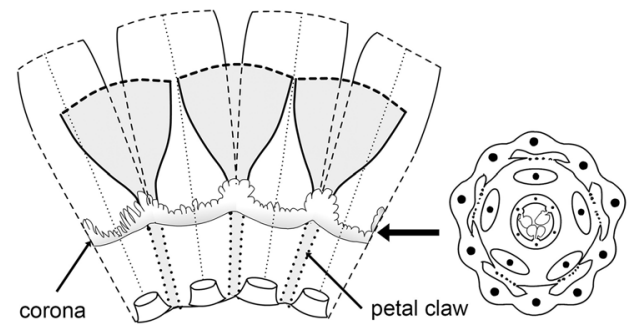

Series Anomalae and Turnera

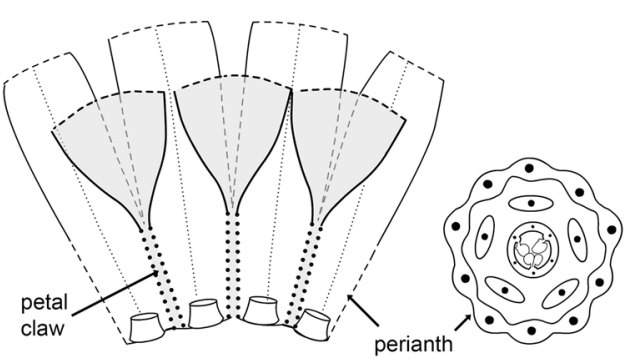

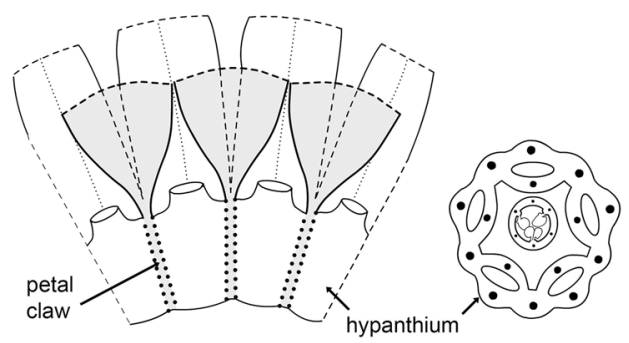

the throat [90]; this perianth tube is $6-18 \mathrm{~mm}$ long. The same happens in Afroqueta (Fig. 2), but the perianth tube is only $0.5-3 \mathrm{~mm}$ long [18].

In Loewia (Fig. 2), the calyx tube does not show major veins, according to Urban (1896) there are 35-40 delicate veins [19], and the petals' claws are adnate all along the calyx tube [90].

Connation and adnation are deeper in Adenoa, Piriqueta and Turnera (Fig. 2), because the perianth tube has only 10 veins [19], 5 of which represent the fusion of the lateral veins of the sepals with the vein along the claw of each petal (Gonzalez 2001; Gonzalez et al. 2012).

Staminal filaments of Erblichia (Fig. 1) are adnate at the base to a sepal and are free from each other [25, 26, 27]. In Mathurina and Stapfiella, there are conspicuous nectaries at the insertion of the staminal filaments on the sepals. In Arboa, the staminal filaments are not adnate to the sepals, because there is an annular free corona between perianth and androecium [23].
In Hyalocalyx (Fig. 1), the staminal filaments are adnate to the calyx tube only at the base, on the external face [26, 27] and are free from one another [25]. In Tricliceras (Fig. 1), Loewia, Adenoa, Piriqueta, and many species of Turnera (Fig. 2), they are adnate to the perianth tube in the same way. The stamens of Streptopetalum (Fig. 1) are attached to the perianth tube $20-33 \%$ of its length [26]; therefore, the basal portion of the tube is in fact an appendicular hypanthium.

The staminal filaments of Adenoa (Fig. 1) and a few species of Turnera are almost free, barely adnate to the perianth tube at the base, but in T. calyptrocarpa and $T$. hebepetala (ser. Microphyllae) they are also briefly connate [26], developing a slender annular structure $0.25-0.40 \mathrm{~mm}$ long (Arbo 2000; Gonzalez 2001).

Turnera rubrobracteata (ser. Conciliatae) and T. reginae (ser. Anomalae) display staminal filaments connate at different heights above adnation to calyx or perianth [26] (Arbo 2005, 2008). 
In Afroqueta (Fig. 2), the margins of the staminal filaments are shortly adhering $(0.4 \mathrm{~mm})$ to the petal claws and connate at the base $[25,26,27]$. In the species of Turnera ser. Anomalae and ser. Turnera (Fig. 2), the staminal filaments show marginal adnation to petal claws and connation usually up to the throat of the flower, developing nectar pockets [28] and defining an appendicular hypanthium (Arbo 1986, 2005; Gonzalez 2001).

Perianth appendices (coronas, ligules, emergences) [23]

The only genus of Turneraceae with a free corona, inserted between perianth and staminal filaments, is Arboa (Fig. 1). Afroqueta and Piriqueta (Fig. 2) have an annular corona, laciniate, fixed at the perianth throat, on the base of the petal blades and on the sepals. In one brevistylous flower of Turnera reginae, a streak of filiform appendices was found at the same location (Arbo 2005). The petals of Erblichia and Tricliceras (Fig. 1) have a small ligule, which can also be found in a few species of Turnera ser. Capitatae and ser. Salicifoliae (Arbo 1997, 2000; Gonzalez 2001).

\section{Placentation}

The Turneraceae have a tricarpelar unilocular ovary, usually with a few to many ovules arranged in parietal placentation. The only exception is the genus Stapfiella (Figs. 1, 3c), in which each ovary has only one ovule and basal placentation [35].

In most genera, each placenta is linear. In Turnera and Piriqueta, the placental bundles often merge into one bundle that runs parallel to a sutural bundle originated by the fusion of the marginal bundles of carpels (Gonzalez 2001). The length of the placenta is variable and in relation to the number of ovules developed. In pauciovulate ovaries, the placenta is short, less than half of the ovary length.

The ovules are usually inserted along a slender stripe on the placental bundle. In mature fruits, the placental bundle appears as a prominent line along the middle vein on the inner face of each valve (Fig. 3d, e). In a few genera: $E r$ blichia, Mathurina, Arboa and Adenoa, the placenta is wide, the ovules are inserted along many rows [36]. The funicles or the scars of their insertion can be observed on the inner face of the dehiscent fruit valves (Fig. 3b).

Size, shape, and parts of the seed

Turneraceae seeds are small, only a few species have seeds that are more than $4 \mathrm{~mm}$ long [52]. The largest seeds are found in Erblichia (4-5 mm) and Stapfiella (3-4.6 mm), while the smallest are found in Hyalocalyx $(1.5-1.6 \mathrm{~mm})$. In Turnera, seeds vary across the whole size range: large seeds occur in $T$. glaziovii $(4.9 \mathrm{~mm})$, and small ones in $T$. argentea, T. diamantina Arbo and T. curassavica Urb. $(1.2-1.6 \mathrm{~mm})$. Ripe seeds are usually very dark, almost black (Fig. 3c).

The seeds of Turneraceae develop from anatropous ovules, with the hilum and the micropyle located at the base, the chalaza at the apex, and the linear raphe along one side (Gonzalez and Arbo 2013). In some cases, a cellular proliferation [50] can be observed at the chalazal end of the raphe. The proliferation is notable for its dark color in immature seeds with light brown surface. This contrast disappears in ripe seeds, which become completely dark. The proliferation is found in seeds of Mathurina (Fig. 4d) and various species of Turnera and Piriqueta (Gonzalez and Arbo 2013).

Seeds are straight [46, 48] in Mathurina (Fig. 4d), Stapfiella (Fig. 4e, f) and Tricliceras (Fig. 5b). They are curved in other genera, such as Adenoa (Fig. 4a), Hyalocalyx (Fig. 5a), Afroqueta (Fig. 5d), Streptopetalum (Fig. 5e), and many species of Piriqueta and Turnera; when the seed is curved, the raphe is located at the concavity (Fig. 5a, d-f). In rapheal view [47, 49], they are usually obovoid and slendering towards the exostome (Fig. 5c). When the seed is markedly curved, as in Hyalocalyx, the rapheal view allows a frontal sight of the exostome (Fig. 6a).

The exostome [72-75] is conical in Arboa, Erblichia (Fig. 4c), Stapfiella lucida (Fig. 4e) and Mathurina (Fig. 8f), hemisphere shaped in Adenoa, Hyalocalyx, Tricliceras, Piriqueta and species of Turnera (Fig. 6b, d), and it is parrot-beak shaped in Streptopetalum serratum (Fig. 6e) and Afroqueta. The exostome is usually shorter in length than in diameter, but it is longer in Stapfiella lucida (Fig. 6c) and Streptopetalum serratum (Fig. 5e).

The upper edge of the exostome is marked by a rim (Figs. 5b, e; 6a, b) in all genera except for Arboa, Erblichia (Fig. 4c), Mathurina (Fig. 8f) and Stapfiella (Fig. 6c). In Turnera sidoides, the rim develops into an annular crest (Gonzalez and Arbo 2013). The ratio rim/exostome diameter is variable [75], sometimes the exostome is bulky (Fig. 6d), but when it is small, its diameter may correspond to just $1 / 3$ of the rim (Fig. 6a).

The hilum [51] is usually located on the rapheal side next to the exostome rim (Fig. 6b), but in Adenoa, Arboa, Erblichia (Fig. 4a-c) and Mathurina (Fig. 8f), it is properly on the exostome, close to the base.

The chalaza [76] is obtuse in Adenoa, Arboa, Erblichia, Mathurina (Fig. 4a-d), Hyalocalyx (Fig. 5a), and Piriqueta. It is prominent in Tricliceras (Fig. 5b) with the surface markedly concave in Loewia, Afroqueta (Fig. 5cd), Stapfiella (Fig. 4e) and Streptopetalum. Turnera shows all the range of variation (Gonzalez and Arbo 2013).

Sometimes, when the chalaza is prominent [77-80], an outcropping develops with the same sculpturing of the seed 

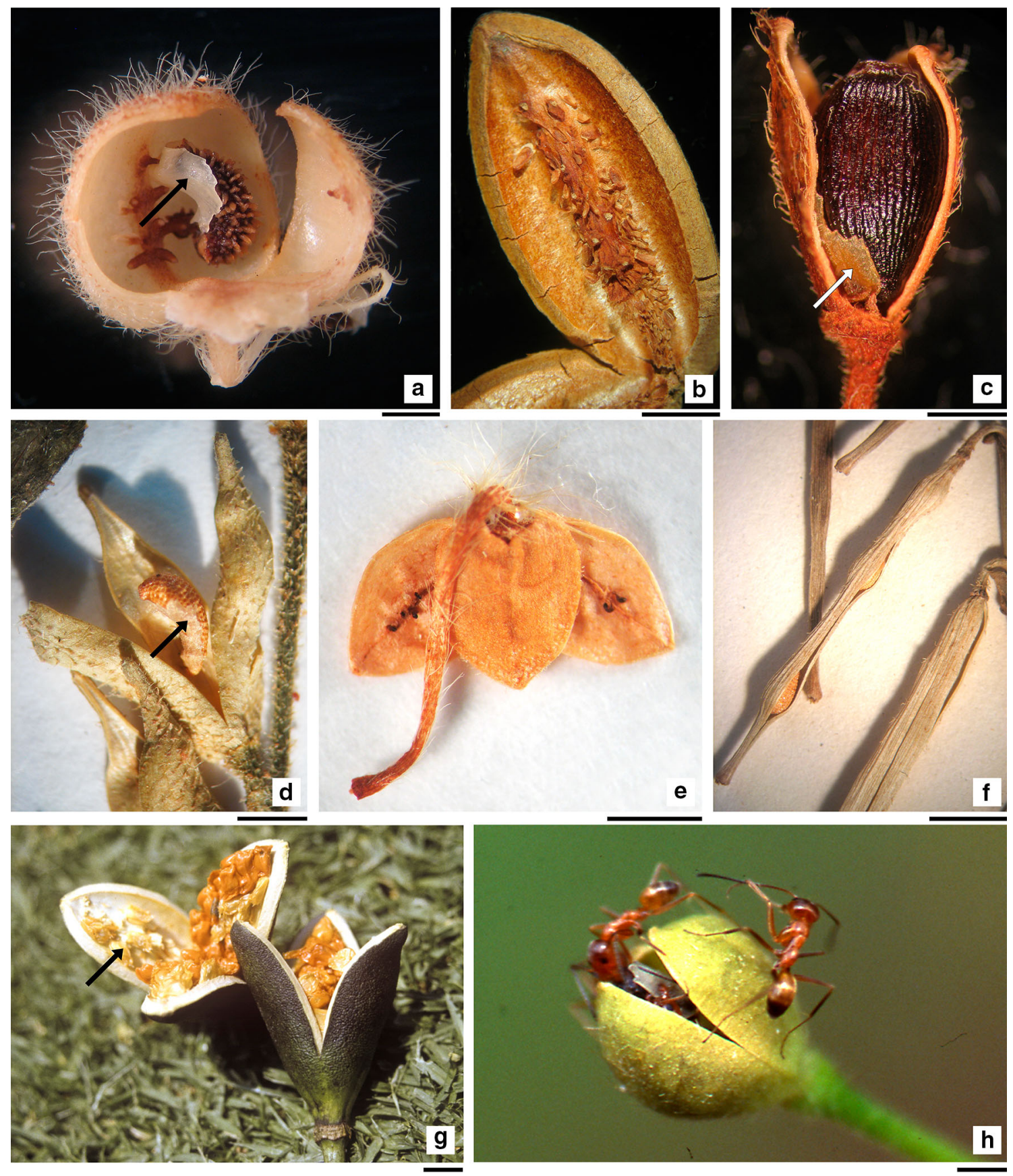

Fig. 3 Dehiscent fruits of Turneraceae: a Turnera sidoides subsp. carnea, almost ripe fruit, valve inner face showing insertion of a crested seed (Solís Neffa et al. 271); b Erblichia odorata, valve inner face, funicles and scars arranged in several rows (Jiménez et al. 1531); c Stapfiella ulugurica, ripe fruit without a valve, the only seed inserted at the base (Mlangwa et al. 1548); d Streptopetalum serratum

(Fig. 4e). The base of the chalaza is occasionally marked by a slight constriction (Fig. 4f, arrow). The orientation of the chalaza surface is variable [80], towards the apical pole (Fig. 5b), intermediate (Fig. 5c-d), or towards the raphe (Fig. 5f).
(Dinter 7530); e Hyalocalyx setiferus, inverted fruit (Schlieben 6338); f Tricliceras longipedunculatum, siliqua-shaped capsule (Schlieben 9283); g Erblichia odorata, seeds covered with orange-red aril (photo A. García Mendoza); h Piriqueta cistoides subsp. caroliniana, ants collecting seeds (photo T. Feldman). Scale bars $\mathbf{a}=2.5 \mathrm{~mm}, \mathbf{b}$, $\mathbf{f}, \mathbf{g}=6 \mathrm{~mm}, \mathbf{c}=1 \mathrm{~mm}, \mathbf{d}, \mathbf{e}, \mathbf{h}=2 \mathrm{~mm}$; arrow indicates aril

Micromorphology of seed coat (episperm)

Considering structure and sculpturing, there are two basic types of seed coat: reticulate and crested [55-56]. The reticulate seed coat and its variants, striate-reticulate and 

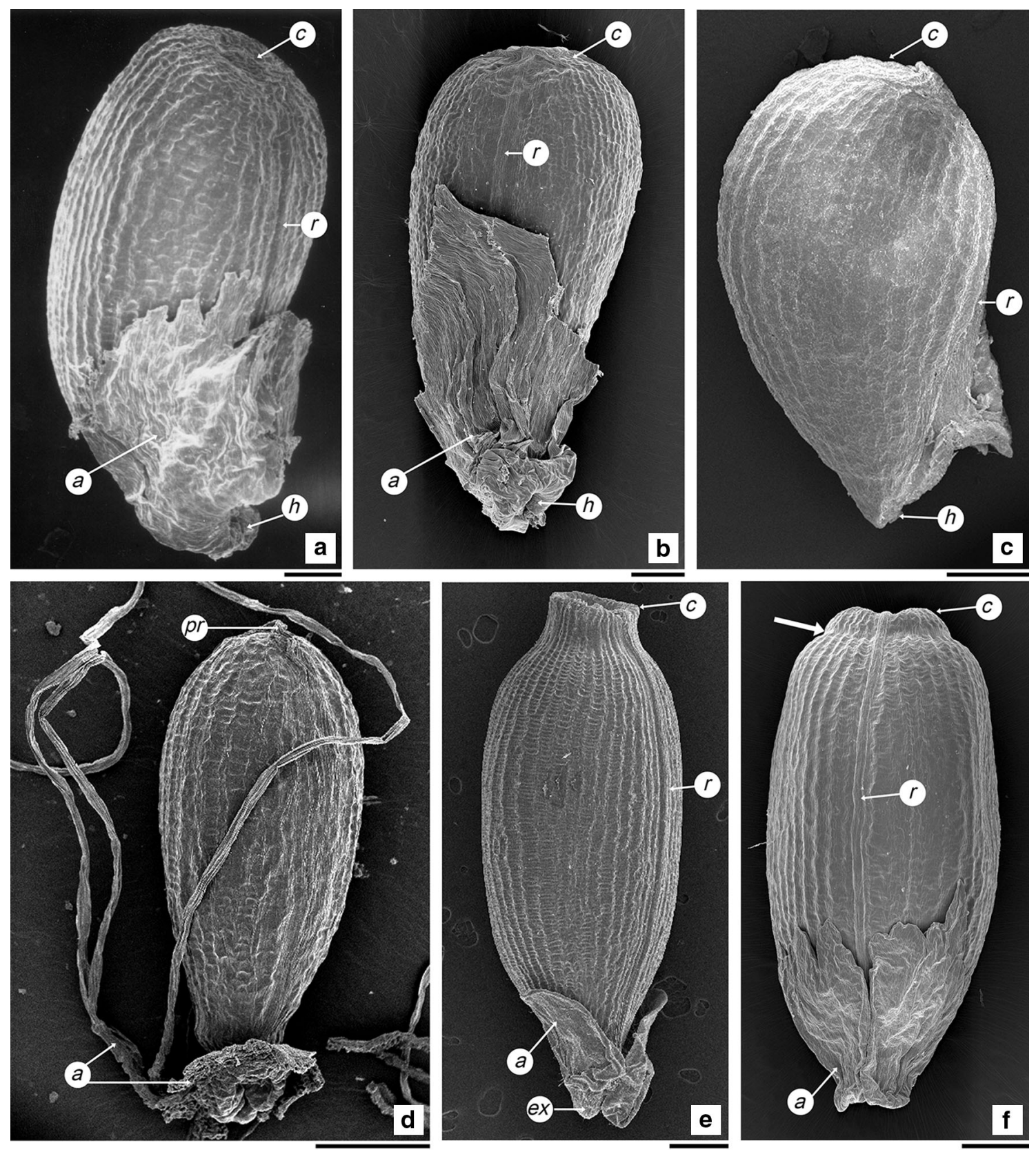

Fig. 4 Seeds of Turneraceae with striate seed coat: a, c-e lateral view, b, f rapheal view; a Adenoa cubensis (Acuña 12577); b Arboa antsingyae (Leandri 2173); c Erblichia odorata, aril insertion along the raphe (Mc Pherson 9999); d Mathurina penduliflora (Friedman 2444); e Stapfiella lucida with an outcropping chalaza (Lewalle

3494); f Stapfiella ulugurica with a slight constriction at the base of the chalaza (arrow) (Mlangwa et al. 1548). Scale bars a, b, $\mathbf{d}-\mathbf{f}=0.5 \mathrm{~mm}, \mathbf{c}=1 \mathrm{~mm} . a$ aril, $c$ chalaza, $e x$ exostome, $h$ hilum, $p r$ proliferation, $r$ raphe

striate, are due to the interaction of endotesta and exotegmen; the crested seed coat is exclusive to Turnera sidoides (ser. Leiocarpae, Fig. 3a), and it is mostly originated by the exotesta (Gonzalez and Arbo 2013).

The reticulate seed coat (Fig. 5) is present in Afroqueta, Hyalocalyx, Loewia, Piriqueta, Streptopetalum, Tricliceras and most species of Turnera (ser. Annulares, ser. Capitatae, ser. Conciliatae, ser. Leiocarpae, ser. Microphyllae,

ser. Papilliferae, ser. Sessilifoliae, and ser. Turnera). The reticule knots [59] are sometimes prominent; they are acute in Piriqueta racemosa, and rounded in Tricliceras (Figs. 5b, 6f) and some species of Turnera ser. Leiocarpae (Gonzalez and Arbo 2013).

The areoles [60] may be outstanding (Fig. 5d) or hardly perceptible (Fig. 5f). They are usually transverse-rectangular (Fig. 5b, arrow) or square, sometimes penta- or 

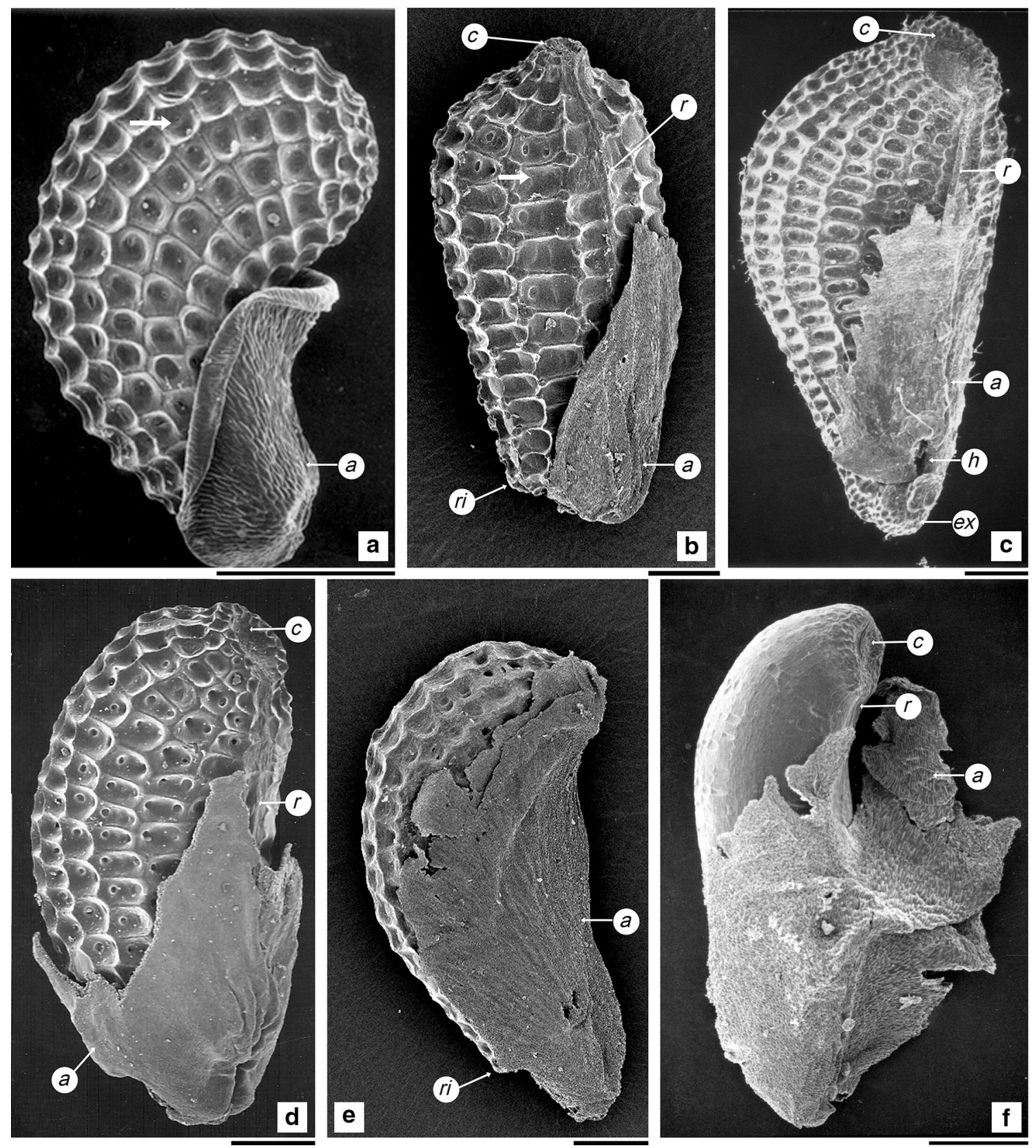

Fig. 5 Seeds of Turneraceae with reticulate seed coat: a, $\mathbf{d}-\mathbf{f}$ lateral view, b, c rapheal view. a Hyalocalyx setiferus with some pentagonal areoles (arrow) (Decary 8041); b Tricliceras pilosum, rectangular areoles (arrow) (Dinklage 8); c Loewia glutinosa with concave chalaza (Gillett and Newbould 19170); d Afroqueta capensis (Wall

hexagonal (Fig. 5a, arrow). Areoles shape and depth are set by the endotesta cells (Gonzalez and Arbo 2013). This stratum of the seed coat [57] consists of only one layer of cells in Adenoa (Gonzalez et al. 2012), Arboa (Fig. 7a), Hyalocalyx (Fig. 7b), Loewia, Stapfiella, Streptopetalum (Fig. 7c), Tricliceras (Fig. 7d), Piriqueta and Turnera (Gonzalez and Arbo 2013); while in Erblichia and Mathurina (Fig. 7e, f), it has several layers. sn); e Streptopetalum serratum exostome upper edge with a rim (Stannard and Gilbert 1107); f Turnera hermannioides (Harley et al. 15618). Scale bars $\mathbf{a}-\mathbf{f}=0.5 \mathrm{~mm}$. $a$ aril, $c$ chalaza, ex exostome, $h$ hilum, $r$ raphe, $r i$ rim

The reticule areoles [61] lacking punctiform cavities (just concaves) occur in Hyalocalyx (Fig. 7b) and species of Piriqueta and Turnera; areoles with one punctiform depression are exclusive to species of the American genera Piriqueta and Turnera (Gonzalez and Arbo 2013). The areoles with two punctiform cavities characterize the African genera Loewia (Fig. 5c), Afroqueta (Fig. 6g), Streptopetalum (Fig. 7c), and Tricliceras (Figs. 5b, 7d), 

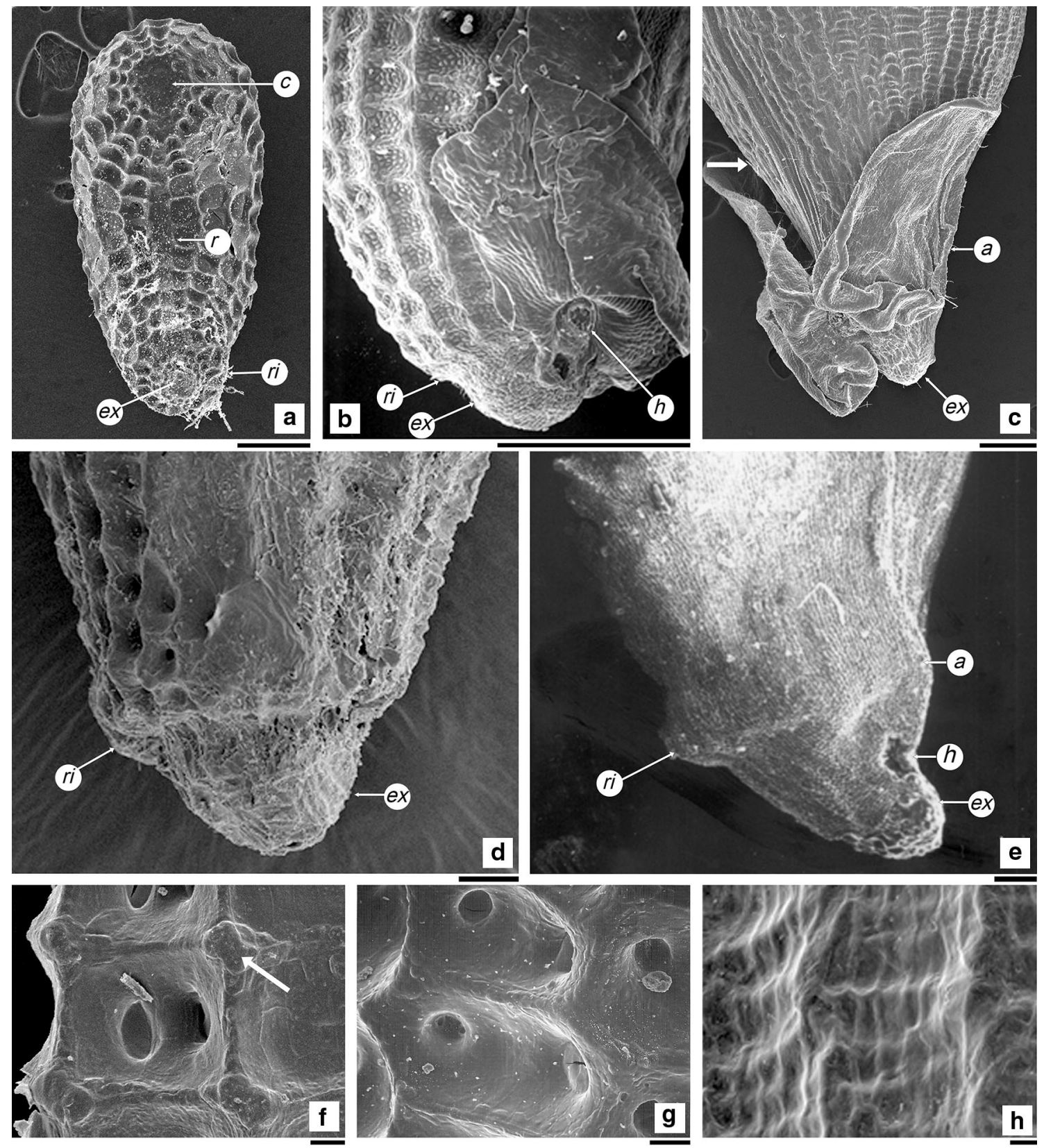

Fig. 6 Seeds of Turneraceae: a Hyalocalyx setiferus, rapheal view, small exostome (Schlieben 6338); b Turnera argentea, aril insertion (Huber and Tillett 2809); c Stapfiella lucida, exostome upper edge without a rim (arrow) (Lewalle 3494); d Turnera rubrobracteata, bulky exostome (Kuhlmann 6656); e Streptopetalum serratum, exostome parrot-beak shaped (Dinter 7530); f Tricliceras

even though they are also found in some shrubby species of Piriqueta (Arbo 1995; Gonzalez and Arbo 2013).

The size of the areoles [62-64] is variable in each seed, the maximum is found on the antiraphe side, in the region of largest seed diameter. The average maximum surface of the areoles ranges from $0.006 \mathrm{~mm}^{2}$ in Turnera stenophylla to $0.1 \mathrm{~mm}^{2}$ in Tricliceras pilosum (Willd.) R. Fern. longipedunculatum, prominent reticule knots (arrow) (Stuhlmann 957); g Afroqueta capensis, areoles with two punctiform cavities (Wall sn); h Stapfiella ulugurica, detail of striate seed coat (Mlangwa et al. 1548). Scale bars $\mathbf{a}-\mathbf{c}=0.25 \mathrm{~mm}, \mathbf{d}, \mathbf{e}=0.1 \mathrm{~mm}, \mathbf{f}, \mathbf{g}=50 \mu \mathrm{m}$, $\mathbf{h}=20 \mu \mathrm{m} . a$ aril, $c$ chalaza, $e x$ exostome, $h$ hilum, $r$ raphe, $r i$ rim

The striate-reticulate seed coat is present in most of the species of Turnera ser. Anomalae, ser. Salicifoliae and ser. Stenodictyae (Gonzalez and Arbo 2013).

The striate seed coat (Fig. 4), in which areoles can not be recognized clearly or measured on the seed surface, is present in Adenoa, Arboa, Erblichia, Mathurina and Stapfiella. The seed coat of Adenoa was described as 

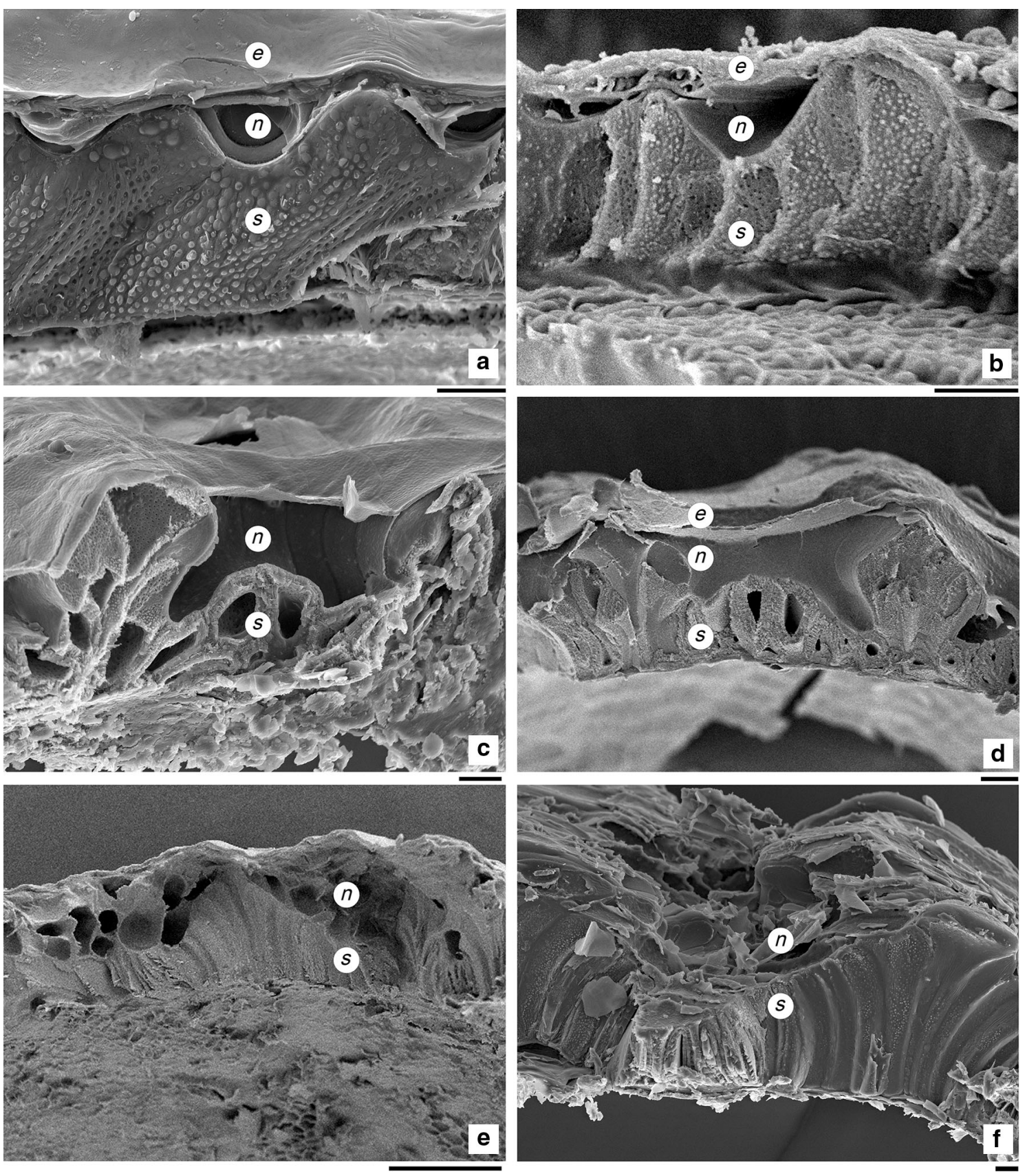

Fig. 7 Seed coat sections: $\mathbf{a}, \mathbf{b}$ concave endotesta cells; $\mathbf{c}, \mathbf{d}$ endotesta cells with two punctiform cavities; $\mathbf{e}, \mathbf{f}$ endotesta of several cell layers. a Arboa antsingyae (Leandri 2173); b Hyalocalyx setiferus (Schlieben 6338); c Streptopetalum serratum (Stannard and Gilbert 1107);

striate-reticulate (Gonzalez et al. 2012), but not even with SEM was it possible to measure the surface of the areoles (Fig. 8b).

The seed surface appearance is determined by the structure and variability of the epidermal cells [65-66]. The shape of epidermal cells is the same all over the seed sculpture except in some species of Turnera ser. Leiocarpae, where they have different size and shape: cells d Tricliceras longipedunculatum (Stuhlmann 957); e Erblichia odorata (McPherson 9999); f Mathurina penduliflora (Friedman 2444). Scale bars $\mathbf{a}-\mathbf{d}, \mathbf{f}=20 \mu \mathrm{m}, \mathbf{e}=0.2 \mathrm{~mm}$. $e$ epidermis (exotesta), $n$ endotesta, $s$ exotegmen sclereids

located on the reticule ridges are large with smooth or convex outer wall, while cells located on the areoles are smaller and papillose (Fig. 6b). This group includes Turnera sidoides, which has a crested seed coat; epidermal cells are different in the crests and depressions (Gonzalez and Arbo 2013).

Commonly, the outer walls of the epidermal cells are flat (Fig. 6g) or convex, with smooth or striated cuticle. 

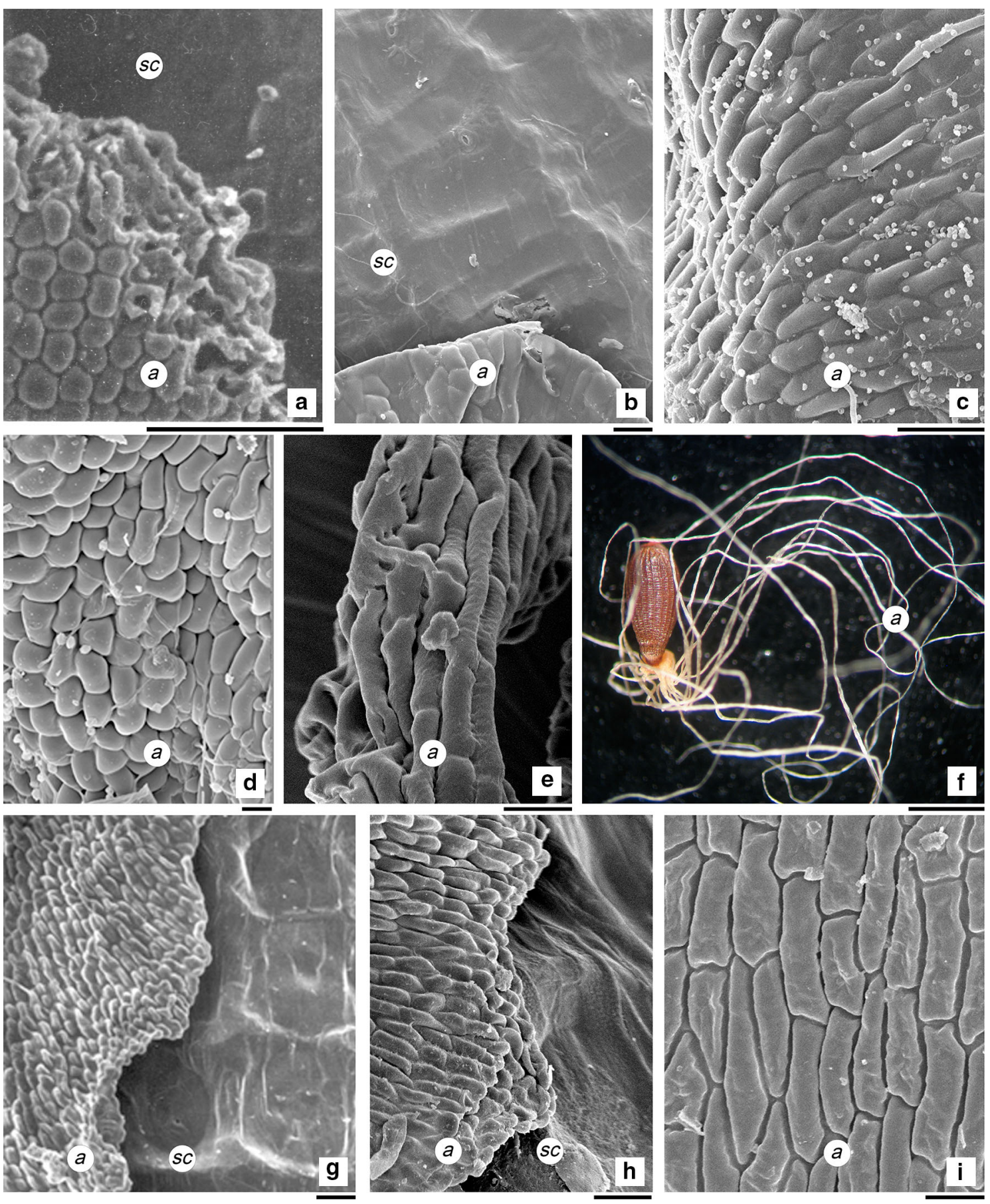

Fig. 8 Aril: a, $\mathbf{i}$ flat cells; $\mathbf{c}, \mathbf{d}$ dome shaped cells; $\mathbf{g}, \mathbf{h}$ papillose cells. a Afroqueta capensis (Wall sn); b Adenoa cubensis (Acuña 12577); c Hyalocalyx setiferus (Schlieben 6338); d Loewia glutinosa (Gillett and Newbould 19170); e Mathurina penduliflora, aril thread; f seed

However, in many species of Turnera and Piriqueta, the epidermal cells have papillae of different shapes [67-68]. In most species of Piriqueta there are finger-like papillae, while filiform papillae are found in species of Turnera, ser. Salicifoliae, ser. Stenodictyae and ser. Anomalae. Hemispheric and part of aril (Friedman 2444); g, h Streptopetalum serratum (Dinter 7530-S, Stannard and Gilbert 1107); i Tricliceras longipedunculatum (Stuhlmann 957). Scale bars $\mathbf{a}-\mathbf{c}, \mathbf{g}=50 \mu \mathrm{m}, \mathbf{d}=10 \mu \mathrm{m}$, $\mathbf{e}, \mathbf{h}, \mathbf{i}=20 \mu \mathrm{m}, \mathbf{f}=1 \mathrm{~mm} . a$ aril, $s c$ seed coat

and mammiform papillae occur in species of Turnera ser. Anomalae, ser. Annulares, ser. Capitatae, ser. Leiocarpae (Fig. 6b) and ser. Salicifoliae (Gonzalez and Arbo 2013).

The presence of epicuticular wax [71] shaped as thin sticks (Gonzalez and Arbo 2013) is exclusive to several 
species of Turnera ser. Leiocarpae including Turnera sidoides. It is mainly observed in immature seeds.

\section{Aril}

All the seeds of Turneraceae possess a live fleshy aril (Fig. 3a), which is membranous when dry (Fig. 3c, d). Live aril is white (Fig. 3a) or whitish except in Erblichia odorata, where it is reddish-orange (Fig. 3g).

The aril is inserted around the hilum (Fig. 6b), except for Erblichia (Fig. 4c) and some species of Turnera ( $T$. blanchetiana, $T$. hermannioides, $T$. joelii) where it is also inserted on the basal portion of the raphe. It is glabrous except in a few species of Turnera (Gonzalez and Arbo 2013).

The aril may be shorter or many times longer than the seed [81-88]. It is very short in some species (Fig. 4 e), sometimes it is unilateral, limited to the rapheal area (Fig. 5 b), or may cover also the sides of the seed (Fig. 5e). In Erblichia, the aril almost doubles the seed length and it is very broad, its edges overlap on the opposite side of the raphe, so that the seed is completely enveloped (Fig. 3g); its cells have a high content of fatty substances.

The aril may be entire (Fig. 5a), lobed (Fig. 5d) or laciniate (Gonzalez and Arbo 2013); in Mathurina (Fig. 8f), with pendulous dehiscent fruits, the aril has some particular features and it is many times longer than the seed and also unusually wide. However, it does not cover the seed at all [87] because it is divided into thread-like segments almost to the base [84].

The external cells of the aril [81] may be flat (Fig. 8a, i), dome shaped (Fig. 8c, d) or papillose. In Piriqueta and Turnera, each cell may have one or several papillae (Gonzalez and Arbo 2013). Aril cells of Mathurina are smooth (Fig. 8e). Streptopetalum is the only African genus which shows some papillose cells (Fig. 8g, h).

\section{Phylogenetic analyses}

The morphological dataset consisted of 91 characters examined in 102 taxa. The matrix contained $1.63 \%$ missing data and all characters were parsimony informative. Nine trees were obtained using $k=4, k=3$, and $k=2$. A strict consensus of the 27 most parsimonious trees is shown in Fig. 9. All genera were inferred as monophyletic.

Most of the nodes at the base of the tree are low to moderately supported (JK values from 52 to 78; Bs values from 0.09 to 0.71). Piriqueta and Turnera lack JK support, and exhibit a Bs value of 0.02 .

In the strict consensus tree (Fig. 9), the monotypic American genus Erblichia is sister to all the other Turneraceae. The next diverging lineages consist of Mathurina, Arboa (a clade of two species), Stapfiella (a clade of two
Fig. 9 Strict consensus of the 27 trees derived from the cladistic analyses using implied weights with $k 2,3$, and 4 . Numbers above and below branches refer to jackknife frequencies and Bremer support values. Letters indicate the nodes for which character substitutions are listed. Within Turnera clade, letters indicate $A O$ ser. Anomalae, $A U$ ser. Annulares, CA ser. Capitatae, CO ser. Conciliatae, $L E$ ser. Leiocarpae, MI ser. Microphyllae, PA ser. Papilliferae, SA ser. Salicifoliae, $S E$ ser. Sessilifoliae, $S T$ ser. Stenodictyae, $T U$ ser. Turnera. Roman numbers refer to clades according to the text

species) and Hyalocalyx. The genus Tricliceras is sister to the remaining genera; the African genera Loewia, Afroqueta and Streptopetalum (node G) are sister to the clade (node J) that gathers Adenoa, Piriqueta and Turnera with sepals connate up to half of their length [18] and a 10-veined perianth tube [19]. Adenoa is sister to Piriqueta (node I) and Turnera is monophyletic (node K). Within Turnera, the position of some species is variable according to the $k$ value.

Erblichia is discriminated by the color of the aril [86] and Mathurina by the pendulous fruit [45] and aril divided into filaments almost to the base [84]. Arboa is singled out by the free corona [23], stamens insertion [27] and granulate fruit [42]. Stapfiella is distinguished by the basal placentation [35], while Hyalocalyx has inverted fruit [45] and low seed average diameter [53]. Tricliceras bears setiform glandular hairs and emergencies [2, 3], cymose inflorescence [12], ligulate petals [23] and siliqua-like fruit [44]. Loewia has a perianth tube with more than 20 delicate veins [19] and a low ratio rim/exostome diameter [75]. Afroqueta has nectaries on the abaxial side of leaf blade [8] and a corona fixed on the perianth [23], while Streptopetalum has setiform glandular hairs [2] and staminal filaments adnate to the perianth tube up to the throat [26]. Adenoa is characterized by a number of apomorphies, such us staminal filaments almost free [26], fruit valves with several rows of seeds [36], gynoecium longer than corolla [38], and high seed average diameter [53]. Piriqueta is circumscribed by the porrect stellate hairs [3] and the corona fixed on the perianth [23]. Synapomorphies of Turnera include the lack of a floral pedicel [17], warted, granulate or tuberculate fruit [42], lower seed average length/width ratio [54] and the seed areoles without punctiform cavity [61].

Within the monophyletic genus Turnera, there are four main groups. Clade I (node L) includes the species of ser. Capitatae, ser. Annulares, ser. Stenodictyae and ser. Salicifoliae with pilose staminal filaments [24] and styles [40], longitudinal seed coat ridges prevalence [58] and concave chalaza [79]; it is sister to the remaining three clades (II, III, and IV) gathered together in a large clade (node M).

Clade II is small, assembling both species of ser. Papilliferae (T. caatingana and T. chamaedrifolia) with $T$. diffusa and T. collotricha (ser. Microphyllae). 
Node A

Char 30: $0 \rightarrow 1$

Char. 86: $1 \rightarrow 0$

Node B

Char. 57: $0 \rightarrow 1$

Node C

Char. 27: $0 \rightarrow 1$

Char. 31: $0 \rightarrow 1$

Char. 42: $0 \rightarrow 1$

Node D

Char. 4: $1 \rightarrow 0$

Char. 39: $0 \rightarrow 1$

Char. 51: $1 \rightarrow 0$

\section{Node E}

Char. 13: $0 \rightarrow 1$

Char 18: $0 \rightarrow 3$

Char. 55: $2 \rightarrow 0$

Char. 58: $0 \rightarrow 1$

Char 60:1 $\rightarrow 0$

Char. 74: $1 \rightarrow 0$

Char. 90: $0 \rightarrow 1$

Node $\mathbf{F}$

Char. 20: $1 \rightarrow 0$

Char. 27: $0 \rightarrow 3$

Char. $37: 2 \rightarrow 1$

Char. 61: $2 \rightarrow 0$

Char. 90: $1 \rightarrow 2$

Node G

Char. 77: $0 \rightarrow 1$

Char. 79: $0 \rightarrow 1$

Char. 80: $0 \rightarrow 1$

Node $\mathbf{H}$

Char. 16: $1 \rightarrow 2$

Char. 90: $2 \rightarrow 3$

Node J

Char 18: $3 \rightarrow 2$

Char. 19: $1 \rightarrow 2$

Char 30: $1 \rightarrow$

Node K

Char. 17: $0 \rightarrow 1$

Char. 42: $0 \rightarrow 1$

Char 54:1 $\rightarrow 0$

Char. 61: $0 \rightarrow 2$

Node L

Char 4: $0 \rightarrow 1$

Char. 8: $0 \rightarrow 3$

Char. 24: $0 \rightarrow 1$

Char 40: $0 \rightarrow 1$

Char. 58: $1 \rightarrow 0$

Char. 79: $0 \rightarrow 1$

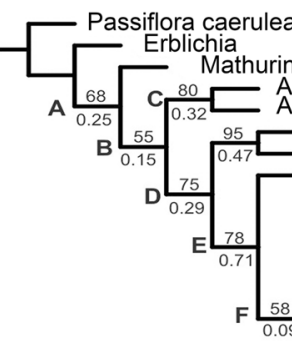

arboa bernerian

- Arboa antsingyae

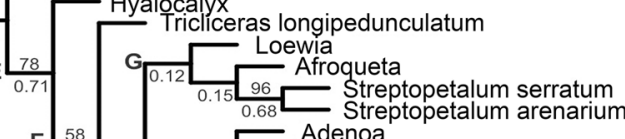

0.09 I Adenoa Piriqueta racemosa

$1 \sqrt{0.09} \begin{aligned} & 0.03 \square \\ & \end{aligned}$

Piriqueta nanuzae

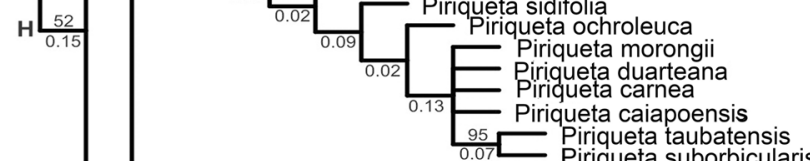

ta suborbicularis

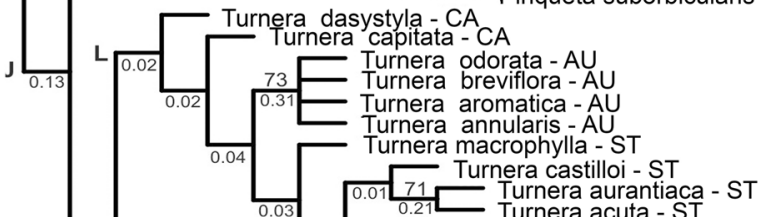

Node M

Char. 53: $2 \rightarrow 0$

Node $\mathbf{N}$

Char. 0: $1 \rightarrow 0$

Char 42:1 $\rightarrow$

Char. 53: $0 \rightarrow 1$

Node 0

Char 14: $0 \rightarrow 1$

Char. 15: $0 \rightarrow$

Char. 41: $1 \rightarrow 2$

Char. 48: $3 \rightarrow 0$

Char. 75: $1 \rightarrow 0$

\section{Node $\mathbf{P}$}

Char. 2: $0 \rightarrow 2$

Char. 25: $0 \rightarrow 1$

Char. 40: $0 \rightarrow 1$

Node Q

Char. 8: $3 \rightarrow 0$

Char. 14: $1 \rightarrow 0$ Char. 17: $1 \rightarrow 0$

Char. 22: $0 \rightarrow 1$

Char. 24: $0 \rightarrow 1$

Char. 42: $0 \rightarrow 1$

Char. 50: $1 \rightarrow 0$

Char. 52: $0 \rightarrow 2$

Char. 54: $1 \rightarrow 2$

Char. 55: $0 \rightarrow 3$

Char. 56: $0 \rightarrow 1$

Char 60: $0 \rightarrow 1$

Char. 67: $3 \rightarrow 1$

Char. 74: $0 \rightarrow 2$

Char. 75: $0 \rightarrow 2$

Char. 81: $0 \rightarrow 2$

\section{Node R}

Char. 12:1 $\rightarrow$

Char. 16: $2 \rightarrow 4$

Char. 55: $0 \rightarrow 1$

Char 58: $1 \rightarrow 0$

Char. 66: $0 \rightarrow 2$

Char. 81: $2 \rightarrow 0$ 
Clade III (node $\mathrm{N}$ ) includes all the species of ser. Leiocarpae and both species of ser. Sessilifoliae, with smooth fruits [42]. Clade IV (node P) is integrated by two groups, one including the only species of ser. Conciliatae: T. rubrobracteata and two species of ser. Microphyllae (T. hebepetala, T. calyptrocarpa). The other group gathers all the species of ser. Turnera and ser. Anomalae, with staminal filaments adnate up to the throat [26] and high average seed length/width ratio [54]. Both groups within clade IV are moderately supported (60 and $70 \mathrm{JK}$, and 0.17 and $0.54 \mathrm{Bs}$, respectively), as well as some small subclades within Turnera.

\section{Character optimization}

Only ten morphological characters are not homoplastic, eight binary characters and two multistate: three floral characters $[28,35,90]$, five seed characters $[56,57,65,68$, $74]$, and two aril characters [83, 86]. Base chromosome number [89] is a multistate character not homoplastic either. Optimizations of nine of them are illustrated in Fig. 10.

The basal state of nectar pockets [28] is their absence; they appear only once in the clade gathering the species of Turnera ser. Turnera and ser. Anomalae.

Placentation [35]: parietal placentation is the ancestral state, which evolves to one ovule of basal placentation only in Stapfiella. This is a diagnostic feature for the genus.

Seed coat design due to endotesta and exotegmen or exotesta [56]: the evolution occurred in Turnera sidoides (ser. Leiocarpae), where the crested seed coat is produced mainly by the exotesta.

The endotesta of seeds [57] is made of several layers in Erblichia and Mathurina. It evolves into a one-layered stratum in the next node.

The epidermal cells of the seed coat are generally equal all over the surface [65]. The evolution into different cells on ridges and areoles occurred in a group of species of ser. Leiocarpae.

The upper edge of the exostome [74] does not have a rim in seeds of Erblichia, Mathurina, Arboa and Stapfiella; in the next node it evolves developing a rim. Finally, in $T$. sidoides (node $\mathrm{Q}$ ), the rim rises into an annular crest.

Aril pubescence [83]. The plesiomorphic state is glabrous; it evolves into pilose only in a subclade integrated by T. panamensis (ser. Salicifoliae), T. princeps and T. marmorata (ser. Capitatae).

Aril color [86]. It evolves only once from orange-red in the outgroup and Erblichia, to white or whitish in the other genera. This is a diagnostic character for Erblichia.

Petals degree of adnation [90]. Petals are free (state 0) in the basal genera, and they are adnate at the base to the calyx tube (state 1) in Hyalocalyx; they are adnate along 1/3-1/2 of the calyx tube (state 2 ) in Tricliceras, and fused up to the throat (state 3 ) in the other genera.

The other 80 characters show homoplasy, optimizations of nine of them are shown in Fig. 11. Some of the characters related with adnation and connation of floral whorls are important to circumscribe genera, i.e., calyx connation [18], the number of veins in the calyx/perianth tube [19], perianth appendices [23] and staminal filaments adnation [26]. Epiphyllous flowers [14], connation of staminal filaments [25], and type of seed coat [55] are valuable characters to infer groups within Turnera. Pedicel presence/ absence [17] and fruit exocarp [42] are useful characters at both the generic and the infrageneric level.

\section{Discussion and conclusions}

A comparison of the topologies derived from morphological trees and molecular analyses is difficult to make because of the great differences in taxon sampling between the two type of analyses. However, the main similarities and differences among them are summarized in Table 1; data from Truyens et al. (2005) were not considered because all their results were incorporated in Chafe (2009). The position of the African genera in our analyses is similar to the results of Chafe (2009), they are in a basal position; while in Thulin et al. (2012), they are in a derived position. Adenoa is allied with Erblichia and Mathurina in Chafe (2009). These genera share with Arboa some structural features as the styles divergent at the base [39] and the seeds arranged in several rows along each fruit valve [36]. In our trees, Adenoa is associated with Piriqueta in a clade, which is sister to Turnera, like in Thulin et al. (2012). This association also has morphological support because these genera have a 10 -veined perianth tube.

It seems like the acquisition of a floral tube is linked with some sort of evolutionary advantage to the Turneraceae, since it occurs in $66 \%$ of the genera: Erblichia, Mathurina, Arboa and Stapfiella. The only ones without a calyx tube occupy a basal position in our topology. Hyalocalyx, which is sister to the remaining genera, has a 15 -veined calyx tube.

The morphological complexity of the floral tube increased in several steps: (1) the adnation of petal claws to calyx [90] found in Tricliceras and Loewia, developing a perianth tube. (2) The adnation of staminal filaments [26] to the perianth tube: in Afroqueta there is a brief marginal adnation while in Streptopetalum, the adnation takes place along $1 / 3-1 / 2$ of the tube, turning that region into an appendicular hypanthium. (3) The fusion of lateral sepal veins with the main petal vein, shaping a 10-veined 


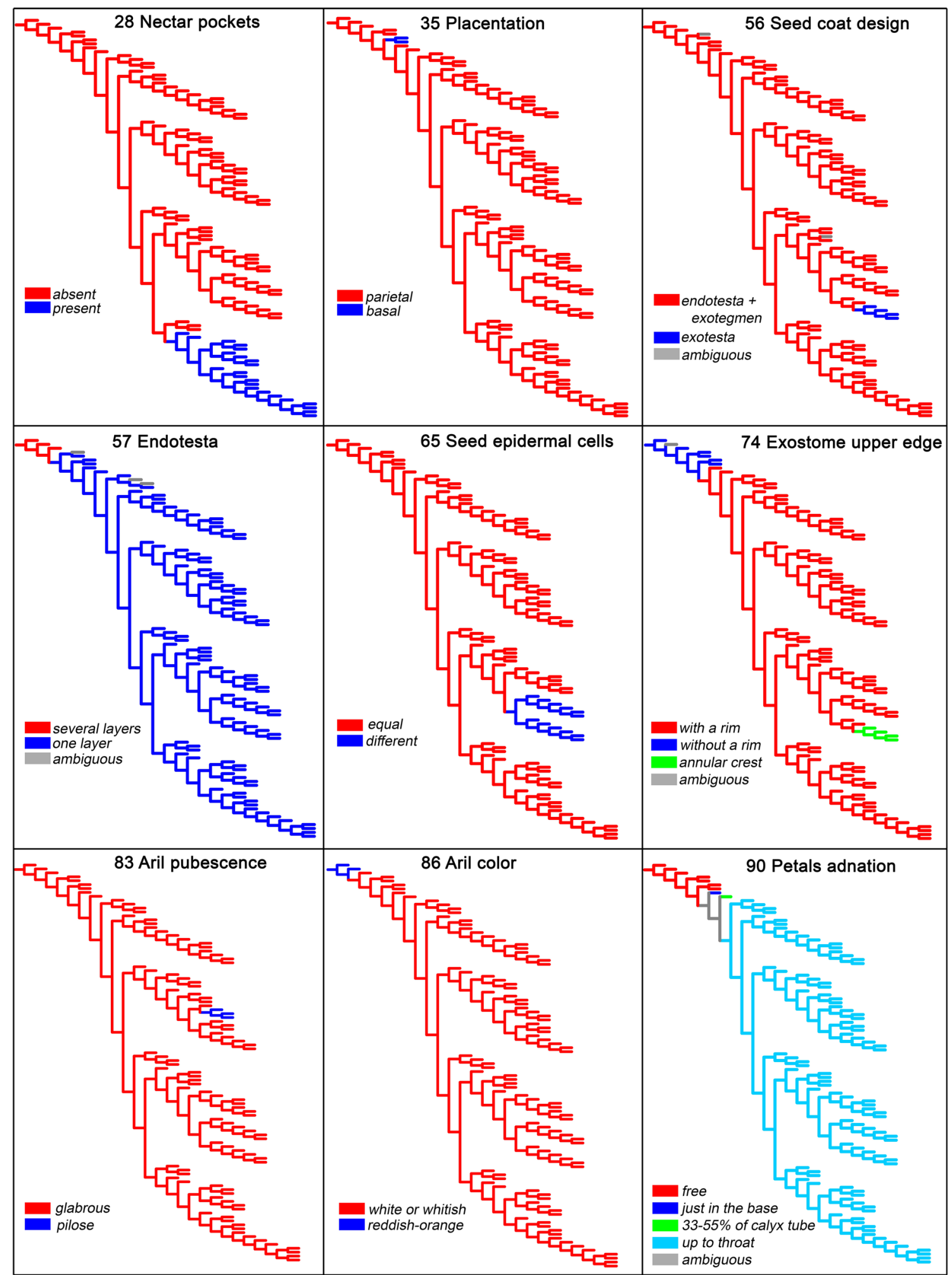

Fig. 10 Optimization of non-homoplastic characters. The number of each character, its shortened name, and states are indicated to the left of the tree skeletons

perianth tube in Adenoa, Piriqueta and Turnera [19]. (4) The development of nectariferous pockets [25-28] by means of the staminal filaments marginal adnation and connation up to the throat found in ser. Turnera and ser. Anomalae; in this case, the whole tube is an appendicular hypanthium. 


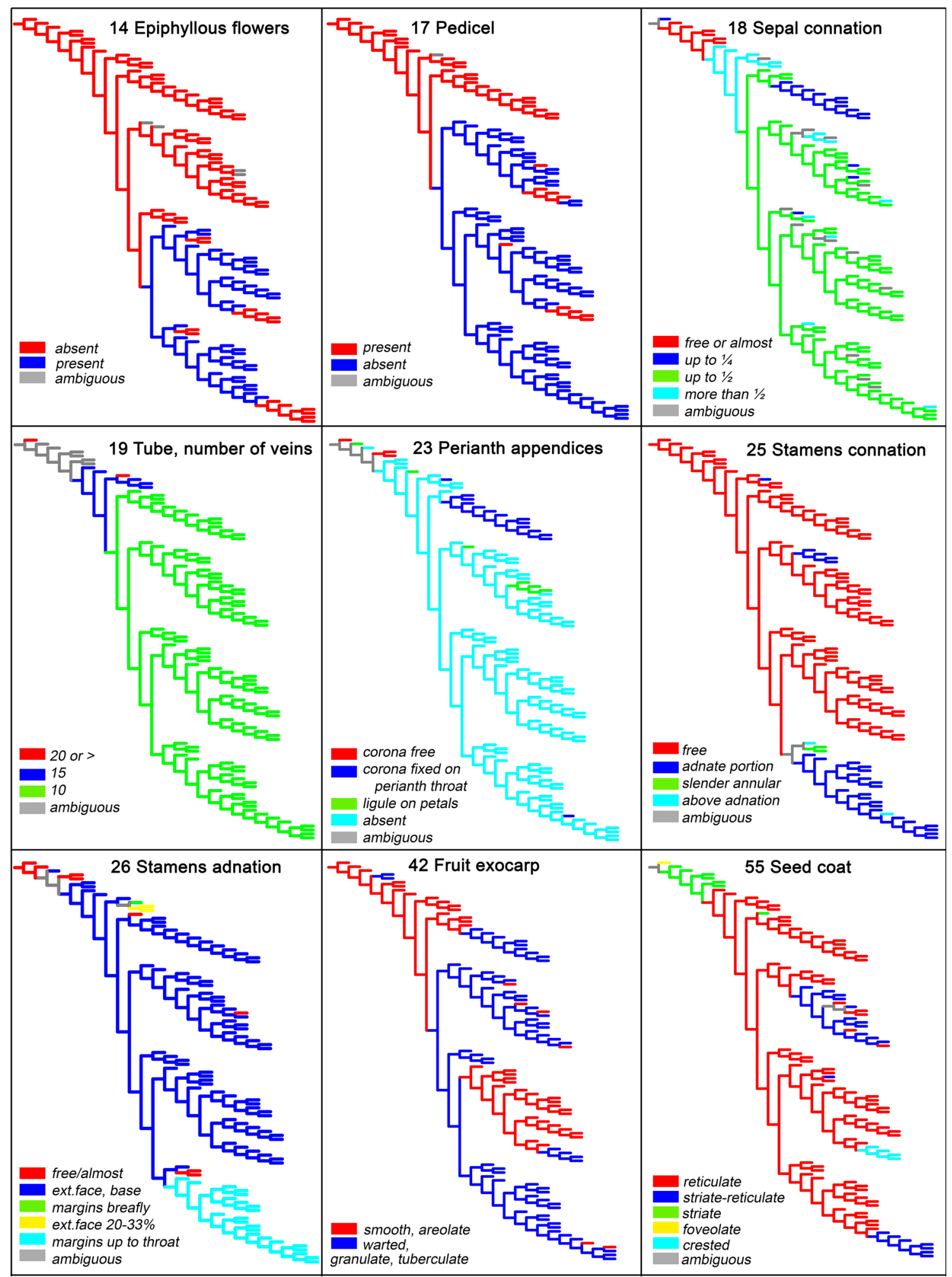

Fig. 11 Optimization of homoplastic characters. The number of each character, its shortened name, and states are indicated to the left of the tree skeletons

The brief adnation found in Afroqueta seems like a morphological step prior to the one found in Turnera ser. Turnera and ser. Anomalae, producing long nectariferous pockets. Adnation of staminal filaments [26] to perianth tube is a homoplastic character; marginal adnation appeared in Adenoa, where it is very brief, and then in 
Turnera series Anomalae and Turnera, where it is well developed.

The color of arils seems to be related to seeds dispersion. The reddish-orange aril of Erblichia is associated with ornitochory (Thulin et al. 2012). Passiflora caerulea L. has seeds with enveloping red aril (Deginani 2001) similar to the one of Erblichia, but the fruit is an indehiscent berry. Probably in both cases, the seeds are dispersed along with birds' feces.

Myrmecochory (Fig. 3h) has been cited for several species of Turnera (Barrett 1978), Piriqueta (Arbo 1995) and the Malagasy genus Arboa (Thulin et al. 2012). It has also been recorded in Turnera oculata Story (Jaarsveld 2012), one of the two African species of the genus. In the other genera, the dispersion is probably carried out also by ants, given the characteristics of the aril, which becomes an elaiosome, much appreciated by these insects. Pijl (1982) observed that ants react very quickly to the presence of elaiosomes, probably due to the existence of volatile compounds associated to the lipids. This author also considers that the presence of extrafloral nectaries in Turnera would attract the ants to diaspores. Cuautle et al. (2005) analyzed the effects of ant behavior and presence of extrafloral nectaries on seed dispersal of Turnera ulmifolia (=T. velutina C.Presl).

The red-orange aril of Passiflora caerulea looks like a plesiomorphic feature in Turneraceae, since it exists only in Erblichia; while all the other genera have a white or whitish aril, typical of mirmecochory. The only exception is Mathurina, where the aril, divided into long threads, is an adaptation to anemochory.

The addition of seed characters to the cladistic analysis led to several changes in the morphological trees with respect to Turnera. There is a better resolution of the series, which are distributed in four main clades. In molecular phylogenetic trees (Truyens et al. 2005; Chafe 2009), the only monophyletic series was ser. Turnera, characterized by a base chromosome number $x=5$.

Series Capitatae, ser. Stenodictyae and ser. Salicifoliae form clade I including also ser. Annulares, which was associated with ser. Turnera and ser. Anomalae in the previous morphological analysis (Arbo and Espert 2009).

Turnera chamaedrifolia, with $x=13$ (ser. Papilliferae), is associated with $T$. diffusa with $x=7$ (ser. Microphyllae) in molecular analyses (Truyens et al. 2005; Chafe 2009). In our clade II, both species of ser. Papilliferae ( $T$. caatingana and $T$. chamaedrifolia) are related to $T$. diffusa and $T$. collotricha, two species of ser. Microphyllae. The base number $x=13$ found in $T$. chamaedrifolia probably originated by aneuploidy from a species with $2 n=4 x=28$ chromosomes (Fernández 1987).

Series Leiocarpae was paraphyletic in both the previous morphological (Arbo and Espert 2009) and molecular phylogenetic trees (Truyens et al. 2005; Chafe 2009); here, all the species are grouped in clade III where both species of ser. Sessilifoliae are nested. Turnera sidoides has several apomorphies and, in particular, its seeds are matchless in the family. In the molecular phylogenetic analyses (Truyens et al. 2005; Chafe 2009), the subspecies of $T$. sidoides formed a separate clade, unresolved among the first diverging lineages of the tree, like in the previous cladistic analyses (Arbo and Espert 2009). In the present study, this species fits in clade III ser. Leiocarpae- ser. Sessilifoliae, and interestingly, it is in a rather derived position.

In a previous morphological analysis (Arbo and Espert 2009), all species of ser. Microphyllae were gathered in one clade, whereas in this study $T$. calyptrocarpa and $T$. hebepetala, with a slender basal annular connation of staminal filaments, are gathered with $T$. rubrobracteata, the only species of ser. Conciliatae. They are integrated in clade IV with ser. Turnera + ser. Anomalae, which present nectar pockets. This is consistent with molecular phylogenetic analyses (Truyens et al. 2005; Chafe 2009), in which $T$. calyptrocarpa is related to $T$. cearensis and $T$. bahiensis, the only species of ser. Anomalae analyzed.

Acknowledgments We are grateful to Abisaí J. García Mendoza and T.S. Feldman for their kind permission to use photographs of the fruits of Erblichia odorata and Piriqueta cistoides subsp. caroliniana, illustrated in Fig. 3 and to all curators of the herbaria for allowing us to access collections.

Gordon Mc Pherson kindly sent us seeds of some genera. We are indebted to Brigitte Marazzi and one anonymous reviewer for useful suggestions that improved the manuscript. This study was possible thanks to the initial support from a J.S. Noyes Grant of the Missouri Botanical Garden to M.M.A., and a Grant from the Consejo Nacional de Investigaciones Científicas y Técnicas-Argentina (CONICET, Grant \# PIP 112- 200801-01457).

\section{References}

APG III (2009) An update of the Angiosperm Phylogeny Group classification for the orders and families of flowering plants: APG III. Bot J Linn Soc 161:105-121

Arbo MM (1977) Adenoa, nuevo género americano de Turneraceae. Hickenia 1:87-91

Arbo MM (1979) Revisión del género Erblichia (Turneraceae). Adansonia, sér 2, 18:459-482

Arbo MM (1986) Paraguay, centro importante de especiación en las Turneráceas. Candollea 41:211-218

Arbo MM (1990) Turnéracées. In: Bosser J, Cadet T, Julien HR, Marais W (eds) Flore des Mascareignes: La Reunion, Maurice, Rodrigues. Fascicle, vol 98, pp 1-6

Arbo MM (1995) Turneraceae Parte I. Piriqueta. Fl Neotrop monograph, vol 67, p 156

Arbo MM (1997) Estudios sistemáticos en Turnera (Turneraceae). I. Series Salicifoliae y Stenodictyae. Bonplandia 9:151-208

Arbo MM (2000) Estudios sistemáticos en Turnera (Turneraceae) II. Series Annulares, Capitatae, Microphyllae y Papilliferae. Bonplandia 10:1-82 
Arbo MM (2005) Estudios sistemáticos en Turnera (Turneraceae) III. Series Anomalae y Turnera. Bonplandia 14:115-318

Arbo MM (2008) Estudios sistemáticos en Turnera (Turneraceae) IV. Series Leiocarpae, Sessilifoliae y Conciliatae. Bonplandia 17:107-334

Arbo MM, Espert SM (2009) Morphology, phylogeny and biogeography of Turnera (Turneraceae). Taxon 58:457-467

Barrett SCH (1978) Heterostyly in a tropical weed: the reproductive biology of the Turnera ulmifolia complex. Canad J Bot 56:1713-1725

Bremer K (1994) Branch support and tree stability. Cladistics 10:295-304

Chafe PDJ (2009) Molecular phylogenetics and breeding system evolution of the Turneraceae. Msc Thesis, York University, Toronto, Canada

Cuautle M, Rico-Gray V, Diaz-Castelazo C (2005) Effects of ant behaviour and presence of extrafloral nectaries on seed dispersal of the Neotropical myrmecochore Turnera ulmifolia L. (Turneraceae). Biol J Linn Soc 86:67-77

Deginani NB (2001) Las especies argentinas del género Passiflora (Passifloraceae). Darwiniana 39:43-129

Farris J, Albert V, Källersjö M, Lipscomb D, Kluge A (1996) Parsimony jackknifing outperforms neighbor joining. Cladistics 12:99-124

Fernández A (1987) Estudios cromosómicos en Turnera y Piriqueta (Turneraceae). Bonplandia 6(1):1-21

Goloboff PA (1993) Estimating character weights during tree search. Cladistics 9:83-89

Goloboff PA (1999) Analyzing large data sets in reasonable times: solutions for composite optima. Cladistics 15:415-428

Goloboff PA, Farris S, Nixon K (2008a) Tree analysis using new technology. Cladistics 24:774-786

Goloboff PA, Carpenter JM, Salvador Arias J, Miranda Esquivel DR (2008b) Weighting against homoplasy improves phylogenetic analysis of morphological data sets. Cladistics 24:758-773
Gonzalez AM (2001) Nectarios y Vascularización Floral en especies de Piriqueta y Turnera (Turneraceae). Bol Soc Argent Bot 36:47-68

Gonzalez AM, Arbo MM (2004) Trichome complement of Turnera and Piriqueta (Turneraceae). Bot J Linnean Soc 144:85-97

Gonzalez AM, Arbo MM (2013) Anatomía y ontogenia de las semillas en Turnera y Piriqueta. Bot Sci 91:399-416

Gonzalez AM, Salgado CR, Fernández A, Arbo MM (2012) Anatomy, pollen, and chromosomes of Adenoa (Turneraceae), a monotypic genus endemic to Cuba. Brittonia 64:208-225

Jaarsveld E (2012) Turnera oculata story var. oculata. Avaliable at: http://www.plantzafrica.com/planttuv/turnoculocul.htm. Accessed 27 August 2014

Shore JS, Arbo MM, Fernández A (2006) Breeding system variation, genetics and evolution in the Turneraceae. New Phytol 171:539-551

Thulin M, Razafimandimbison SG, Chafe P, Heidari N, Kool A, Shore JS (2012) Phylogeny of the Turneraceae clade (Passifloraceae s. 1.): trans-Atlantic disjunctions and two new genera in Africa. Taxon 61:308-323

Tokuoka T (2012) Molecular phylogenetic analysis of Passifloraceae sensu lato (Malpighiales) based on plastid and nuclear DNA sequences. J Pl Res 125:489-497

Truyens S, Arbo MM, Shore JS (2005) Phylogenetic relationships, chromosome and breeding system evolution in Turnera (Turneraceae): inferences from ITS sequence data. Amer J Bot 92:1749-1758

Urban I (1883) Monographie der Familie Turneraceen. Jahrb Königl Bot Gart Berlin 2:1-152

Urban I (1896) Turneraceae, somalenses a D.Robecchi-Bricchetti lectae. Ann Ist Bot 6:189-190

van der Pijl L (1982) Principles of dispersal in higher plants, 3rd edn. Springer-Verlag, Berlin 